Мунько Анна

ORCID iD 0000-0001-6651-9970

E-mail: munkoann@gmail.com

\title{
ІНСТИТУЦІЙНІ ОСОБЛИВОСТІ ДЕРЖАВНОГО РЕГУЛЮВАННЯ СПОЖИВЧОГО РИНКУ УКРАЇНИ
}

\author{
https://doi.org/10.33269/2618-0065-2021-4(10-95-115
}

Анотація. Економічні, політичні, соціально-правові рамки взаємодії між суб'єктами споживчого ринку формуються в інституційному середовищі як сукупності «правил гри» (правила, настанови, норми, санкції тощо), Суб'єктна структура регуляторного впливу на споживчому ринку представлена державними, регіональними інститутами та організаціями, які $\epsilon$ не тільки інститутами політичної влади, а й громадськими інститутами, котрі формують соціально-правове поле функціонування економічних агентів. Зазначені суб'єкти забезпечують функціональну основу реалізації організаційно-інституційного управління споживчим ринком в Україні. Метою статті є дослідження інституційних аспектів відносин, що виникають в процесі державного впливу i саморегулювання споживчих ринків, регулювання їх розвитку як системи заходів 3 державного програмування структури економіки України та областей. Розглянуто безперервний процес впливу на ринок з боку попиту і пропозиції, а також боротьби із «тіньовою» економікою, спрямований на розв'язання завдань, що стоять перед суб'єктами підприємницької діяльності і державою в умовах економічної та законодавчої невизначеності. Визначено сценарії взаємодії суб`єктів національного споживчого ринку, особливості формалізації такої взаємодії 3 урахуванням національної специфіки, а також фактори обмеженої раціональності сторін взаємодії. Обгрунтовано найбільш значущі інституційні проблеми ринку в Україні. Проаналізовано процес організації споживчого ринку України та виявлено домінування неформальних інститутів, що визначають підприємницьку діяльність, та перерозподіл трансакційних витрат за допомогою виплат неформального характеру. Здійснено кількісну оцінку трансакційних витрат суб'єктів підприємницької діяльності на основі даних. Запропоновано шляхи розвитку інституційного середовища державного регулювання споживчого ринку в Україні.

Ключові слова: державне регулювання, споживчий ринок, саморегулювання споживчих ринків, інституційне середовище, трансакційні витрати, обмежена раціональність взаємодії сторін. 
Постановка проблеми. Структуруюча роль споживчого ринку в національній економіці, з одного боку, визначає його елементом регуляторної політики держави, а 3 іншого боку розвивається конкуренція як основна форма існування споживчих ринків у розвинутих країнах, що призводить до все більшої ефективності функціонування стихійних установ кон'юнктурних та структурних пропорцій на ринку. Інституційні особливості регулювання сучасного споживчого ринку пов'язані з розширенням, ускладненням і прискоренням оновлення товарного асортименту, що підвищує рівень трансакційних витрат підприємств; посиленням експертноінформаційної та стейкхолдерських функцій, що стимулює бізнес до їх залучення до процесів розробки і збуту нових видів продукції; трансформацією соціально-економічної структури домогосподарства, що веде до зміни моделей споживання i бюджетування. За цих умов принципово важливим $\epsilon$ узгодження стратегічних принципів і підходів до управління споживчими ринками, лібералізації споживчих ринків та підвищення актуальності довгострокового зростання ефективності використання ресурсів.

Аналіз останніх досліджень та публікацій. Підвалини наукових досліджень щодо державного регулювання ринкових механізмів закладені у працях таких зарубіжних вчених, як С. Брю, Є. Дж. Долана, Дж. М. Кейнса, К. Макконелла, А. Маршалла, В. Мітчела, П. Самуельсона, М. Фрідмена та ін. Вітчизняними науковцями також грунтовно та системно досліджуються механізми державного регулювання ринку товарів та послуг.

Н. Попадинець [1] розглядає процеси державного регулювання споживчого ринку через призму розуміння його як сукупності цілеспрямованого впливу з боку органів державного управління 3 метою його стабілізації та забезпечення збалансованого розвитку.

Т. Князєва, А. Шевченко [2] присвятили свої роботи питанням формування та розвитку ринків, галузей національної економіки. 
Ефективні моделі функціонування ринків, зокрема продовольчого та аграрного, досліджували такі вчені, як Л. Страшинська, Д. Худолій [3]; глобалізаційні аспекти функціонування внутрішнього споживчого ринку Г. Капленко [4], І. Клепанчук, І. Свидрук [5], Л. Чміль [6] та інші; фіскальне регулювання споживчого ринку - О. Десятнюк, В. Сідляр [7] та ін.

Щодо новітніх закордонних досліджень означеної проблематики, то увага в наукових доробках приділяється ролі споживчого кредиту в процесах регулювання ринку товарів і послуг (Д. Бартон [8], Н. Морі, М. Окамура, Т. Охава [9], Дж. Шратен [10] та ін.), а також інструментам цифровізації ринків та впливу їхнього впровадження (Ф. Вербовен, Л. Гжибовськи, Н. Дух-Браун, А. Роман [11]та ін.). Водночас динамічні процеси зміни вихідних умов державноуправлінської діяльності потребують перманентного оновлення та поглиблення досліджень особливостей регулювання споживчих ринків, серед яких чільне місце посідають інституційні складники.

Метою статті $є$ дослідження інституційних аспектів відносин суб єктів споживчого ринку, що виникають в процесі державного впливу i саморегулювання споживчих ринків, регулювання їх розвитку як системи заходів 3 державного програмування структури економіки України та областей.

Методи дослідження. Під час дослідження використано такі загальнонаукові методи дослідження, як діалектичний метод пізнання - вивчення сучасних теоретико-методичних розробок вітчизняних та зарубіжних учених щодо регулювання споживчих ринків, законодавчих та нормативних актів. Методи економіко-статистичного аналізу - оцінювання інституційного середовища споживчих ринків України та трансакційних витрат, а також для виявлення недоліків і невикористаних можливостей щодо удосконалення механізмів державного регулювання споживчих ринків.

Виклад основного матеріалу. Сторонами взаємодії національного споживчого ринку виступають: виробничі та 
торговельні організації; органи державного управління та контролю; саморегульовані організації (асоціації).

Органи державного управління здійснюють регуляторну діяльність щодо споживчого ринку за такими напрямами:

розроблення та реалізація державної політики щодо розвитку роздрібної та оптової торгівлі, а також торговельновиробничої сфери на основі використання ринкових механізмів господарювання, здійснення технічної політики у сфері торговельної діяльності;

сприяння формуванню та товарному насиченню споживчого ринку, виробництву товарів, розширенню їх асортименту та поліпшенню якості 3 урахуванням попиту населення;

розроблення та запровадження правил торгівлі, забезпечення контролю за їх додержанням, здійснення заходів щодо вдосконалення організації торговельного обслуговування;

координація роботи 3 питань розвитку торговельної інфраструктури, розроблення торговельно-технічного обладнання;

державне регулювання цін;

контроль за повнотою та своєчасністю сплати податків та зборів;

детінізація економіки;

взаємодія 3 місцевими органами державної виконавчої влади та органами місцевого самоврядування у сфері забезпечення державного регулювання торговельних відносин.

Сторони взаємодії перебувають в інституційному середовищі як сукупності «правил гри» (правила, настанови, норми, санкції тощо), що визначають економічні, політичні, соціально-правові рамки взаємодії між суб'єктами споживчого ринку.

Суб'єктна структура регуляторного впливу на споживчому ринку представлена державними, регіональними інститутами та організаціями, які є не тільки інститутами політичної влади, а й громадськими, що формують соціально-правове поле функціонування економічних агентів. 
Зазначені суб'єкти забезпечують функціональну основу реалізації організаційно-інституційного управління споживчим ринком в Україні.

Відповідно взаємодія сторін на споживчому ринку характеризується правовими, економічними та організаційними формами впливу на процес соціально-економічного розвитку. Таку взаємодію можна представити у вигляді кількох сценаріїв:

збереження тенденції скорочення об'єктів виробництва в окремих галузях економіки, відсутність істотних структурних та кон'юнктурних змін, що не може гарантувати стійкість соціально-економічного розвитку країни;

орієнтація на отримання максимальних прибутків та виробництво найбільш конкурентоспроможної продукції на внутрішньому та зовнішньому ринках;

відображення інтересів підприємців - інвесторів;

максимізація доходів, спрямованих на розвиток виробництва, та мінімізація доходів, спрямованих на соціальні потреби;

розвиток як реакція на сучасні ринкові тенденції.

Формалізація взаємодії сторін споживчого ринку відбувається 3 урахуванням особливостей національного характеру, до яких можна віднести:

пріоритетність колективних взаємовідносин та моделей соціальної взаємодії;

патерналізм у взаємовідносинах громадян та держави;

консервація в поведінкових моделях;

блокування реалізації ухвалених рішень інституційного рівня через неузгодженість інтересів різних груп економічних агентів або різких змін економічних умов.

Обмежена раціональність сторін взаємодії також обумовлюється: ментальними бар'єрами (культура, традиції, гносеологія мотиваційної сфери, моделі взаємозв'язку); інерційністю у розвитку (механічне копіювання досвіду розвинутих сторін без урахування специфіки національного інституційного середовища).

Витрати домогосподарств свідчать про вподобання громадян, споживчу поведінку, традиції, доходи, модель домогосподарства, економічну структуру. Вони складаються 
також під впливом зміни цін, кліматичних умов та активності виробників. За допомогою дослідження споживання можливо проаналізувати соціально-економічний розвиток суспільства та окремі моделі споживача.

Аналізуючи структуру сукупних витрат домогосподарств за даними Державної служби статистики (витрати i ресурси домогосподарств України за даними вибіркового обстеження життя домогосподарств України у I півріччі 2020 року) можна зробити висновок, що майже весь дохід сім'ї витрачається на споживання, а саме на забезпечення продуктами харчування та непродовольчими товарами та послугами, що стримує споживання інших послуг, а отже i витрат на освіту, відпочинок, розваги, заощадження тощо [12, с. 159]. Це все призводить до зменшення добробуту домогосподарств, що впливає на неефективне формування i використання їх фінансових ресурсів.

Структура споживання непродовольчих товарів і послуг у складі сукупних витрат доводить, що найбільший відсоток витрат у загальній структурі непродовольчих витрат займають витрати на житло, воду, електроенергію, газ - близько 40 \%, на одяг і взуття - трохи більше $10 \%$. Витрати на відпочинок та культуру й освіту становлять всього близько 5 \% [7, с. 82-83].

У процесі виявлення обмеженої раціональної взаємодії під час регулювання споживчих ринків необхідно взяти до уваги такі фактори:

рівень споживчих витрат у сукупних доходах домогосподарств;

динаміку співвідношення між витратами на споживання на споживання та збереженнями;

питому вагу витрат споживчого ринку у валому внутрішньому продукті (далі - ВВП);

рівень інтегрованості логістичної інфраструктури в національному та глобальному господарському просторі;

традиції, звичаї, культуру та структуру споживання, культурно-етнічні та історичні особливості;

державну цінову політику як складову державної економічної та соціальної політики (забезпечення розвитку національної економіки та підприємницької діяльності; 
протидія зловживанню монопольним (домінуючим) становищем у сфері ціноутворення; розширення сфери застосування вільних цін; збалансування ринку товарів та підвищення їх якості, соціальних гарантій населенню в разі зростання цін; надання необхідних економічних гарантій для виробників; орієнтація цін внутрішнього ринку товарів на рівень цін світового ринку).

Інституційне управління організаційним рівнем споживчого ринку (порядок, заданий національними особливостями, чинним законодавством, регуляторними інститутами тощо) передбачає цілеспрямований вплив на обмеження та норми діяльності, зокрема: впровадження нових способів виробництва, отримання нового джерела сировини, виготовлення нового блага, освоєння нових ринків збуту та проведення реорганізації.

Найбільш значущими інституційними проблемами ринку є:

перехідний етап в еволюції домогосподарства в Україні як ринкового інституту;

недостатня регламентація умов взаємодії суб'єктів ринку $[3$, c. 3];

низька споживча грамотність, що створює сприятливі умови для різних форм несумлінного ведення бізнесу;

нерозвиненість норм підприємницької етики;

ослаблення державного контролю у сфері захисту прав споживачів;

На взаємодію всередині організації споживчого ринку суттєво впливає його неоднорідне конкурентне та інституційне середовище як на національному, так і на регіональному рівнях. Відсутність ефективної системи регулювання споживчих ринків призводить до значної кількості небажаних наслідків, пов'язаних із порушенням легального обігу товарних та грошових ресурсів в країні.

Крім того, на підставі аналізу ВВП України, середньої заробітної плати та доходів на душу населення відображаються загальнодержавні тенденції, що визначають ефективність розвитку національної економіки.

Номінальний ВВП відображує зміни як у фізичному обсязі виробництва, так i в ринкових цінах i розраховується як вартість усіх кінцевих товарів та послуг у цінах поточного року. 
Реальний ВВП вимірює вартість обсягу виробництва в економіці із застосуванням фіксованих цін базового року. Саме його аналіз надає можливість визначити зміни реального обсягу виробництва або економічного зростання країни. Результати відносно успішних 2017-2019 рр. формування висхідного періоду економічного циклу, який характеризувався помірним зростанням реального ВВП в межах $3 \%$ за сучасних умов зберегти навряд чи вдасться. Без значних потрясінь, при розумному стимулюванні економіки Україна, ймовірно, змогла б досягти $3 \%$ зростання ВВП. Девальвація реального впливу наднаціональних організацій, розрив глобального ланцюга переміщення ресурсів, товарів та послуг може створити дефіцит у короткочасній перспективі.

За оперативною оцінкою Державної служби статистики України реальний ВВП у I кварталі 2021 року зменшився порівняно 3 попереднім кварталом на 1,1\% (3 урахуванням сезонного фактору), а порівняно з I кварталом 2020 року - на $2 \%[13]$.

Індекс реальної заробітної плати слугує мірилом зміни купівельної спроможності населення в частині формування його трудових доходів, тобто значної частини ресурсів домогосподарств. Середньомісячна реальна заробітна плата $(\%$ до відповідного періоду попереднього року): 2016 рік - 109,0 \%; 2017 рік - 119,1 \%; 2018 рік - 112,5\%; 2019 рік - 109,4 \%; 2020 рік $-107,4 \%$ [13]. Однак порівняння із накопиченим індексом споживчих цін дозволяє зробити висновок, що купівельна спроможність населення зменшилась. Зміни споживчих цін (грудень до грудня попереднього року): 2016 рік - 12,4 \%; 2017 рік - 13,7\%; 2018 рік - 9,8\%; 2019 рік - 4,1 \%; 2020 рік $5 \%$ [13].

Отже, попри стабільно позитивну динаміку доходів населення внесок споживчих витрат у ВВП країни не відповідає реальному стану справ, на що вказує суттєва різниця в динаміці показників. Це так само свідчить про наявність неформальних («тіньових») відносин в організації споживчого ринку та необхідність удосконалення регуляторної політики. 
Інституційне середовище складає систему формальних та неформальних інститутів, характеризується взаємозв'язками та взаємодіями між ними.

Формалізація інституційного середовища регуляторного впливу на споживчий ринок здійснюється через організаційні структури, створені для реалізації певних функцій формальних інститутів та інституцій (правилами, нормативними актами різних рівнів, процедурами). Шляхом формування формальних та неформальних інститутів для кожного рівня управління забезпечується ефективне функціонування споживчого ринку.

До формальних інститутів належать: органи державної виконавчої влади та місцевого самоврядування; політичні інститути; економічні інститути; соціальні інститути.

До неформальних інститутів належать: цінності, традиції; моделі взаємовідносин; стилі управління; ментальні особливості, у тому числі й регіональні; історичний детермінізм.

В умовах адаптації вітчизняного інституційного середовища до загальноєвропейських критеріїв повинні превалювати зміни, що забезпечують заміщення неформальних поведінкових норм учасників ринку формальними інститутами. Однак, сучасні тенденції свідчать про неперервну трансформацію інститутів, коли формальні правила значною мірою замінюються неформальним, перетворюючись у неформальні відносини.

Зазначену тенденцію щодо деформалізації правил підтверджують дані Державної податкової служби України за 2020 рік. Незважаючи на низхідну динаміку економічної активності, надходження до державного та місцевих бюджетів, а також з єдиного соціального внеску в минулому році зросли на 13,5 \%. Сальдо надходжень 3 податку на додану вартість (далі - ПДВ) збільшилося на 36,8\%. У січні - лютому 2021 року обсяги поставок товарів і послуг (база оподаткування ПДВ) зросли на 10,3\% в порівнянні з відповідним періодом минулого року, а сальдо надходжень з ПДВ збільшилося в 1,5 рази (з 17,8 млрд грн до 25, 8 млрд грн). Це стало можливим завдяки ефективному розширенню бази оподаткування за рахунок «тіньової» економіки. Наприклад, загальні доходи 
населення 2020 року без урахування податків становили 3,4 трлн грн, з яких 1,9 трлн - це заробітна плата та інші грошові доходи. Водночас обсяги виручки підприємств торгівлі, які фіксуються через касові апарати, в 2020 році становили менш 1,3 трлн грн. Це може свідчити, що $62 \%$ витрат домогосподарств не фіксується через фіскальний чек та, відповідно, не сплачуються податки і збори до бюджету.

За підрахунками Кабінету Міністрів України питома вага «тіньового сегмента» економіки України становить понад 40 \%, а за підрахунками деяких експертів іiі частка навіть перевищує $60 \%$ ВВП. Зазначене підтверджує наведені вище цифри фіскального сегменту.

Це підтверджують і результати досліджень Київського міжнародного інституту соціології, згідно 3 якими рівень тіньової економіка в Україні у 2018 р. становить 47,2 \% від ВВП та 46,8 \% у 2017 p. [14]. Для порівняння, Національна служба статистики Італії оцінила обсяги тіньової економіки країни за 2017 р. на рівні 12,1 \% ВВП. Справа й у тому, що Україна згідно із дослідженнями «Transparency International» дуже корумпована і тенденція невтішна. Індекс сприйняття корупції (Corruption Perceptions Index), розрахований у 2019 р. показав, що корупційна криза нашої держави поглибилась (126 місце із 180). Сприйняття корупції відображається за шкалою від 100 (немає корупції) до 0 (сильна корупція). У 2019 р. Україна із результатом 30 із 100 втратила шість позицій у порівнянні із 2018 р. [15]. Складниками тіньової економіки України є три види ухилення від податків: приховування доходу від бізнесу (найбільша частка - 56,7 \%), приховування реальної кількості найманих працівників, приховування реальних розмірів виплаченої зарплати або зарплата «у конвертах». Частка останнього значно зросла $318,3 \%$ у 2017 р. до $21,4 \%$ у 2018 p. [14].

Результати досліджень процесу організації споживчого ринку України засвідчили домінування неформальних інститутів, що визначають підприємницьку діяльність; перевалювання неформальних практик ведення господарства. Цьому причиною зокрема, стали суттєві прогалини у нормативно-правовій базі національного господарського, 
бюджетного, фіскального законодавства, що визначає діяльність споживчого ринку. Це сприяє проведенню серед підприємців нефіскальних транзакцій тощо.

Недостатність формальних правил поведінки суб'єктів споживчого ринку не $є$ виключною причиною проявів неформальних норм ведення діяльності. В країнах Центральної і Східної Свропи впровадження офіційних регуляторів ринку сприяло звуженню зон неформальних відносин. В Україні, на жаль, сьогодні можна констатувати певний зворотний ефект упровадження нових формальних регуляторів призводить до активізації неформальних поведінкових моделей та їх розширення.

Інституційне середовище українського ринку знаходиться в стані, що характеризується домінуванням неформальних інститутів. Підтвердженням та одночасно причиною означеної тенденції є те, що суб'єкти господарювання та представники владних структур перебувають в стані, так би мовити, «виживання». Після того, як інститути реалізуються через діяльність суб'єктів, взаємодія між інститутами відбувається на основі узгодження інтересів сторін. Аналіз інституційного середовища споживчого ринку України підтверджує положення теорії суспільного вибору - ухвалення посадовими особами органів державної влади на всіх рівнях таких рішень, які максимізували їх власні функції корисності. Підтвердженням може слугувати, наприклад, активність діяльності контролюючих органів (перевірки планові та позапланові).

I не $є$ секретом, що підприємці постійно стикаються 3 неформальними вимогами представників органів державного нагляду. За цих обставин результатом «узгодження» інтересів сторін $\epsilon$ зменшення штрафних санкцій за порушення господарського, трудового, бюджетного, фіскального законодавства суб'єктами ринку, кількості перевірок тощо. Розповсюдження неформальних угод, їх довгостроковий характер свідчить про перманентність ситуацій. Поширена думка, що ведення діяльність виключно в межах закону $є$ занадто дороговартісним для бізнесу. Це зумовлено значною кількістю часто протилежних формальних правил організації поточної господарської діяльності підприємств. На наш погляд, 
велика кількість перевіряючих органів, дублювання їх повноважень, високі штрафні санкції призводять до дезорганізації діяльності підприємців. Отже, на практиці виконання функцій контролюючих органів стає декларативним.

Розповсюдження неформальних правил здійснення господарської діяльності підтверджується поширеністю таких норм. Тобто якщо, підприємство буде дотримуватися всіх формальних правил ведення господарської діяльності, а інші не будуть, то воно стане неконкурентоспроможним. Іншим фактором впливу $\epsilon$ невизначеність ситуації в регуляторній політиці на споживчому ринку, адже попри декларування на державному рівні підтримки малого підприємництва, послаблення фіскального тиску, дебюрократизацію економіки, фактична результативність таких заходів (якщо вони були запроваджені) зводиться до мінімуму. Згідно із сучасними тенденціями розвитку формальних інститутів, що визначають поточну господарську діяльність, засвідчують, що контроль 3 виконання зазначених заходів з боку органів державної влади не надає жодних гарантій для підприємців, адже остаточне рішення ухвалюють представники контролюючих органів.

Аналіз інституційного середовища споживчого ринку України свідчить про перерозподіл трансакційних витрат за допомогою виплат неформального характеру. Водночас джерелом покриття підвищених трансакційних витрат слугують доходи від неформальної діяльності. Це підтверджує закономірності взаємодії формальних та неформальних інститутів - введення державного формального інституційного обмеження, що здійснює нераціональне розподілення транзакційних операцій між економічними суб'єктами ринку, призводить до розширення неформальної діяльності, тобто до зменшення трансакційних витрат у вигляді легальних виплат до оптимального (адекватного) рівня за їх тенденційно мінімальному значенні. Парадокс функціонування інститутів полягає в тому, що хоча органи влади й мають можливість використовувати силовий тиск на підприємців, трансакційні витрати в довгостроковому періоді рівнозначно виражаються в результаті узгодження інтересів сторін. 
В умовах національного ринку така ситуація інституційної стабільності приймається всіма його учасниками, а також свідчить про низьку ефективність проведених в країні інституційних перетворень.

Очевидно, що не враховано такі аспекти інституційного проєктування:

стислі терміни впровадження нової системи інститутів потребують корегування багатьох правових норм в процесі їх дії, що призведе до зростання трансакційних витрат і рівня невизначеності суб'єктів ринку;

врахування інтересів ключових суб'єктів: зокрема, контрактна система не включає нових форм та інститутів громадського контролю, підвищує вимоги до контролю контрактів без урахування їх реальних можливостей і ресурсів;

різноманітність стимулів і санкцій: підвищення рівня контролю на всіх етапах контрактних відносин супроводжується збереженням набору i рівня санкцій щодо замовників при їх посиленні стосовно постачальникам, що порушує баланс інтересів всіх учасників цього ринку.

Трансакційні витрати суб'єктів споживчого ринку, пов'язані 3 упровадженням регуляторної політики та заходів боротьби із «тіньовою» економікою (рис. 1), доцільно розглянути як з боку суб'єктів підприємницької діяльності, так і органів державної влади.

Кількісна оцінка трансакційних витрат суб'єктів підприємницької діяльності передбачає аналіз даних про якісну характеристику інституційного середовища споживчого ринку України, інформації Державної фіскальної служби України; оцінювання «тіньового» обігу та неформального сектору підприємств. Джерелами інформації також можуть виступати результати інтерв'ю та анкетування керівників підприємств, зокрема щодо невиробничих витрат поточної господарської діяльності та їх основних причин, оцінювання стану інституційного середовища щодо протизаконних дій та неформальних відносин з органами державної влади. 
Науковий вісник : Державне управління № 4(10) 2021

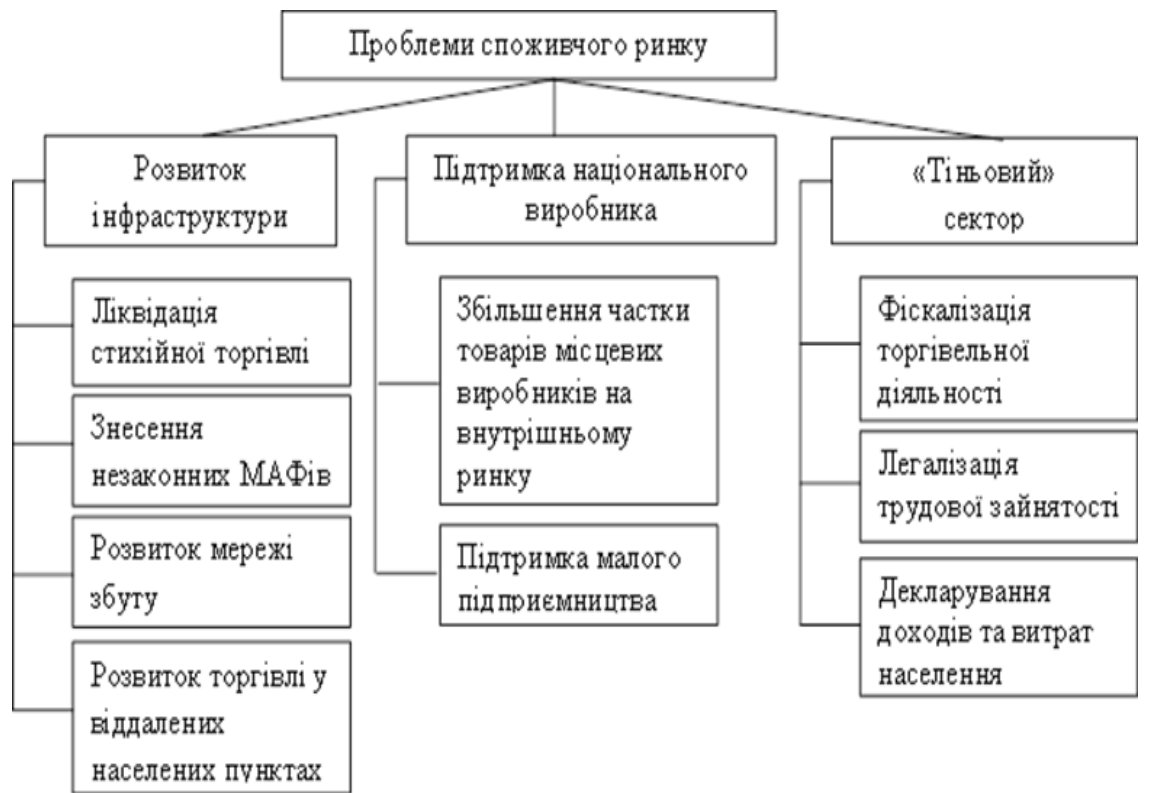

Рисунок 1 - Схема пріоритетних напрямів регуляторної політики щодо розвитку споживчого ринку України

Джерело: розроблено авторкою.

Всього в Україні зафіксовано понад 2,6 мільйона підприємств (згідно з останніми даними Єдиного державного реєстру юридичних осіб, фізичних осіб-підприємців та громадських формувань).

Сумарний обсяг реалізованої продукції за задоволенням споживчих потреб можна представити за допомогою складання обсягу реалізованої продукції, виробленої на основних виробничих фондах (зі стабільним прогнозом) та обсягу реалізованої продукції, виробленої на новостворених виробничих фондах (iз урахуванням ефекту віддачі від вкладених інвестицій вибирають, окупності проекту в середньостроковій перспективі за нормами рентабельності, прийнятними для інвестора).

До трансакційних витрат підприємства належать:

витрати, пов'язані з прискореною реєстрацією;

витрати, пов'язані з обов'язковою сертифікацією товарів;

сертифікація послуг роздрібної торгівлі; 
витрати, пов'язані з діяльністю органів нагляду, включених у ціну товарів споживчого призначення;

неформальні витрати, пов'язані з відносинами із органами влади.

За оцінкою Державної податкової служби (що перебуває нині в процесі ліквідації), втрати Зведеного бюджету України від застосування схем з ухилення (мінімізації) сплати податків складають близько 7,7 млрд дол. США на рік, які можна прирівняти до трансакційних витрат органів державної влади, пов'язаних із деформалізацією відносин на споживчому ринку України.

Серед найбільш популярних схем: зарплата в «конвертах» (втрати - 4,3 млрд дол. США); діяльність «скруток» та конвертаційних центрів (втрати - 1,5 млрд дол. США); офшори (втрати - 0,8 млрд дол. США); операції з підакцизними товарами (втрати - 1 млрд дол. США); збитки державних підприємств (втрати - 0,1 млрд дол. США) [16].

Додатково до трансакційних витрат органів державної влади (бюджетних витрат) відносимо витрати на боротьбу 3 ухиленням від оподаткування.

Насамперед йдеться про впровадження загальнонаціонального декларування доходів громадянами.

До трансакційних витрат, пов'язаних із впровадження такого декларування, відносимо витрати на створення інтегрованої бази даних для кожного платника податків 3 можливістю доступу податкових органів до інформації, що фіксується іншими органами центральної влади та місцевого самоврядування. Це дасть змогу податковим органам самостійно розраховувати суму податку на доходи фізічних осіб (далі - ПДФО) для кожної фізичної особи та контролювати своєчасність і повноту її сплати максимально ефективно.

Іншим напрямом $є$ контроль своєчасності стягнення ПДФО, для підвищення якості якого необхідно встановити чималу пеню за неповну або несвоєчасну сплату, застосовуючи стимулювання у вигляді сплати відсотків на зайво сплачену упродовж року суму податку (наприклад, як у Даніі). Несплата податків має вважатися тяжким кримінальним злочином. 
Отже, серед заходів щодо оптимізації процесу стягнення ПДФО та формування особистої податкової культури громадян доцільно ввести жорстку систему штрафів за нелегальне працевлаштування, мінімізацію та виплату заробітної плати «у конвертах» як для роботодавців, так i для працівників. Найбільш ефективними вважаються такі способи впливу як раптові перевірки підприємств та штрафи, а за відсутності помітного результату від вищеперерахованих заходів можна ввести радикальний захід - кримінальну відповідальність.

На споживчому ринку України можна виділити декілька тенденцій.

Із великими зарубіжними мережами або постачальниками в України працює ще не дуже багато учасників ринку. Як правило, це великі компанії, адже укладати договірні відносини з закордонними партнерами дуже складно, що досить жорстко виставляють свої умови співпраці i не прагнуть їх обговорювати.

Чим менша компанія-постачальник, тим складнішим для неї $\epsilon$ співробітництво 3 мережевими форматами через неспроможність надати необхідну кількість товару в усі мережеві точки.

Щодо умов укладення договірних відносин, особливу увагу звертають на надійність партнерів, великий обсяг закупівель і гнучкість політики партнерів незалежно від торгових форматів.

Водночас закупівельна ціна товару не $\epsilon$ визначальним фактором під час взаємодії. Важливою для учасників споживчого ринку є надійність ділового партнера.

У контрактних відносинах відзначаємо наявність неформальних зв'язків, дотримання неформальних домовленостей і правил ведення бізнесу, підтримання відкритих комунікацій і своєчасне надання зворотного зв'язку.

Сторони у контрактах (купівлі-продажу) прагнуть максимально точно прописати взаємні зобов'язання, однак це не завжди є можливим, тому часто виникає необхідність в укладенні неформальних угод.

Щодо державно-приватного партнерства, то контрактні відносини тут чітко регулюється Законом України «Про державно-приватне партнерство». На стороні приватного 
партнера у договорі, укладеному в рамках державно-приватного партнерства, можуть виступати декілька осіб. Відносини між приватними партнерами та порядок визначення приватного партнера для представництва інтересів інших приватних партнерів у відносинах 3 державним партнером визначаються умовами договору, укладеного між приватними партнерами, або умовами договору, укладеного в рамках державноприватного партнерства. Такі особи несуть солідарну відповідальність за зобов'язаннями, передбаченими договором, укладеним в рамках державно-приватного партнерства.

До ознак державно-приватного партнерства належать: створення та/або будівництво (нове будівництво, реконструкція, реставрація, капітальний ремонт та технічне переоснащення) об’єкта державно-приватного партнерства та/або управління (користування, експлуатація, технічне обслуговування) таким об'єктом; довготривалість відносин (від 5 до 50 років); передача приватному партнеру частини ризиків у процесі здійснення державно-приватного партнерства; внесення приватним партнером інвестицій в об'єкт державно-приватного партнерства [17].

Споживачі можуть реалізувати свої права шляхом укладення відповідних цивільно-правових договорів. Одним із них договорів є договір роздрібної купівлі-продажу.

Зазначимо, що створення та впровадження ефективної системи захисту прав споживачів в Україні з урахуванням кращих практик країн ЄС передбачає повну гармонізацію українського законодавства 3 законодавством СС, сприяння розвитку системи незалежних досліджень якості та безпеки товарів, робіт і послуг на споживчому ринку, підвищення ефективності системи захисту споживачів від небезпечної продукції тощо. Це підвищить рівень превентивного захисту прав споживачів для недопущення та/або зменшення кількості порушень їх прав, підвищить рівень просвіти та поінформованості громадян щодо їх споживчих прав та механізмів їх захисту, усуне 3 ринку недобросовісних підприємців тощо [18].

Як стратегічний вектор розвитку споживчих ринків в Україні можна визначити розробку концепції державної 
стратегії управління в економічній сфері, оскільки іï реалізація сприятиме успіху розпочатих сучасних економічних реформ, створення передумов для якісних перетворень, активізація економічної діяльності в регіонах та територіальних громадах у довгостроковій перспективі [19, с. 7].

Висновки та напрями подальших досліджень. У результаті дослідження засвідчуємо стійку тенденцію щодо розповсюдження неформальних інститутів у функціонуванні споживчого ринку, що підсилюється невизначеністю ситуації в регуляторній політиці на споживчому ринку. Попри декларування на державному рівні підтримки малого підприємництва, послаблення фіскального тиску, дебюрократизації економіки, фактична результативність таких заходів (якщо вони були запроваджені) зводиться до мінімуму. Відтак, унормування процесів державного регулювання споживчого ринку та поглиблений аналіз рівня споживання непродовольчих товарів та послуг; рівня споживання продуктів харчування; рівня харчування вдома міського населення, а у сільського населення - залежно від рівня доступних ресурсів; рівня споживання продуктів харчування та непродовольчих товарів та рівня закупівлі послуг визначають переспективи подальших наукових розвідок.

\section{Список використаних джерел}

1. Попадинець Н. М. Структурно-інституційна модель внутрішнього ринку споживчих товарів. Регіональна економіка. №1. 2020. 123-133.

2. Князєва Т. В., Шевченко А. В. Організаційно-економічні заходи зовнішньоекономічного регулювання захисту споживчого ринку України. Проблеми системного підходу. 2020. № 2 (76). C. 161-169.

3. Страшинська Л. В., Худолій Д. Ю. Напрями державного регулювання продовольчого ринку. The world of science and innovation : abstracts of VII International scientific and practical conference, 2021. C. 882-885.

4. Капленко Г. В. Теоретико-методологічні засади регулювання ринку споживчих товарів України в умовах глобалізації : дис. ... д-ра екон. наук : 08.00.03. Чернігів, 2020. 413 с.

5. Свидрук I. І., Клепанчук О. Ю. Глобалізаційні особливості розвитку внутрішнього ринку України. Вісник ЛТЕУ. Економічні науки. 2021. № 62. URL : http://journalslute.lviv.ua/index.php/visnyk-econom/article/view/755 (дата звернення : 10.10.2021).

6. Чміль Г. Л. Трансформація поведінки економічних суб'єктів споживчого ринку в умовах цифровізації. Сучасні реалії фінансово-економічного розвитку регіонів, галузей, підприємств, бізнесу: монографія. Том 1 / за ред. Л. М. Савчук, Л. М. Бандоріної. Дніпро: Пороги, 2020. С. 374-383.

7. Десятнюк О., Сідляр В. Фіскальне регулювання споживчого ринку України. Світ фінансів. 2020. № 1 (62). URL : http://sf.wunu.edu.ua/index.php/sf/article/view/1297 (дата звернення : 21.10.2021). 


\section{Науковий вісник : Державне управління № 4(10) 2021}

8. Burton D. Political economy and financial regulation: A comparative analysis of the consumer default debt market in the United States of America and the European Union. Journal of Economic Geography. 2019. 19(3). P. 705-722.

9. Mori, N., Okamura, M., Ohkawa, T. Economic Regulation in the Consumer Loans Market. Atlantic Economic Journal. 2020. № 48(4). P. 447-459.

10. Schraten J. Credit and debt in an unequal society: Establishing a consumer credit market in South Africa. Restoring Consumer Sovereignty: How Markets Manipulate Us and What the Law Can Do About it. 2020. P. 1-324.

11. Duch-Brown, N., Grzybowski, L., Romahn, A., Verboven, F. Are online markets more integrated than traditional markets? Evidence from consumer electronics. Journal of International Economics. $2021 . \quad$ URL https://ideas.repec.org/a/eee/inecon/v131y2021ics0022199621000532.html (дата звернення : 10.10.2021).

12. Сидорова А. В., Коваленко А. О. Доходи та витрати населення: статистичне оцінювання, моделювання та прогнозування. Фінанси, облік, банки. 2017. № 1(22). С. 154-162.

13. Державна служба статистики України : вебсайт. URL : http://www.ukrstat.gov.ua (дата звернення : 20.10.2021).

14. Тіньова економіка в Україні. Результати дослідження 2019 року : звіт Київського міжнародного інституту соціологіï. URL : https://cutt.ly/hTaWvj9 (дата звернення : 21.10.2021).

15. Corruption Perceptions Index 2019 : Transparency International. URL : https://www.transparency.org/cpi2019 (дата звернення : 10.10.2021).

16. Державна податкова служба України : вебсайт. URL : www.tax.gov.ua.

17. Про державно-приватне партнерство : Закон України від 01 лип. 2010 р. № 2404-VI. URL : https://zakon.rada.gov.ua/laws/show/2404-17 (дата звернення 21.10.2021).

18. Про схвалення Концепції державної політики у сфері захисту прав споживачів на період до 2020 року: Розпорядження Кабінету Міністрів України; Концепція від 29.03.2017 № 217-р. URL : https://zakon.rada.gov.ua/laws/show/217-2017-\%D1\%80 (дата звернення : 21.10.2021).

19. Latynin M., Pastukh K, Tarasenko D., Shevchenko S., Munko A. Public administration in the economic sphere of Ukraine: strategic approach. Studies of applayed economics. 2021.Vol.39, №5. URL : https://cutt.ly/KTaYMsX (дата звернення : 21.10.2021).

\section{References}

1. Popadynets, N. M. (2020) Strukturno-instytutsiina model vnutrishnoho rynku spozhyvchykh tovariv [Structural and institutional model of the domestic market of consumer goods]. Rehionalna ekonomika - Regional economy, 1. 123-133 [in Ukrainian].

2. Kniazieva, T. V., Shevchenko, A. V. (2020) Orhanizatsiino-ekonomichni zakhody zovnishnoekonomichnoho rehuliuvannia zakhystu spozhyvchoho rynku Ukrainy [Organizational and economic measures of foreign economic regulation of consumer market protection in Ukraine] Problemy systemnoho pidkhodu - Problems of the system approach, 2. 161-169 [in Ukrainian].

3. Strashynska, L.V., Khudolii, D.Iu. (2021) Napriamy derzhavnoho rehuliuvannia prodovolchoho rynku [Directions of state regulation of the food market]. The world of science and innovation, 882-885 [in Ukrainian].

4. Kaplenko, H. V. (2020) Teoretyko-metodolohichni zasady rehuliuvannia rynku spozhyvchykh tovariv Ukrainy v umovakh hlobalizatsii [Theoretical and methodological principles of regulation of the consumer goods market of Ukraine in the context of globalization]. Chernihiv [in Ukrainian].

5. Svydruk, I. I., Klepanchuk. O. Yu. (2021) Hlobalizatsiini osoblyvosti rozvytku vnutrishnoho rynku Ukrainy [Globalization features of Ukraine's domestic market development.]. Visnyk LTEU. Ekonomichni nauky - Bulletin of LTEU. Economic sciences, 62. URL : http://journalslute.lviv.ua/index.php/visnyk-econom/article/view/755 [in Ukrainian].

6. Chmil, H. L. (2020) Transformatsiia povedinky ekonomichnykh subiektiv spozhyvchoho rynku $v$ umovakh tsyfrovizatsii [Transformation of behavior of economic entities of the consumer market in the conditions of digitalization]. Suchasni realii finansovo-ekonomichnoho rozvytku rehioniv, haluzei, pidpryiemstv, biznesu - Modern realities of financial and economic development of regions, industries, enterprises, business. Dnipro: Porohy. 374-383 [in Ukrainian]. 


\section{Науковий вісник : Державне управління № 4(10) 2021}

7. Desiatniuk, O., Sidliar, V. (2020) Fiskalne rehuliuvannia spozhyvchoho rynku Ukrainy [Fiscal regulation of the consumer market of Ukraine]. Svit finansiv - World of Finance, 1. URL : http://sf.wunu.edu.ua/index.php/sf/article/view/1297 [in Ukrainian].

8. Burton, D. (2019) Political economy and financial regulation: A comparative analysis of the consumer default debt market in the United States of America and the European Union. Journal of Economic Geography, 19. 705-722 [in English].

9. Mori, N., Okamura, M., Ohkawa, T. (2020) Economic Regulation in the Consumer Loans Market. Atlantic Economic Journal, 48. 447-459 [in English].

10. Schraten, J. (2020) Credit and debt in an unequal society: Establishing a consumer credit market in South Africa. Restoring Consumer Sovereignty: How Markets Manipulate Us and What the Law Can Do About it. 1-324 [in English].

11. Duch-Brown, N., Grzybowski, L., Romahn, A., Verboven, F. (2021) Are online markets more integrated than traditional markets? Evidence from consumer electronics. Journal of International Economics, 313 URL : https://ideas.repec.org/a/eee/inecon/v131y2021ics0022199621000532.html [in English].

12. Sydorova, A. V., Kovalenko, A. O. (2017) Dokhody ta vytraty naselennia: statystychne otsiniuvannia, modeliuvannia ta prohnozuvannia [Incomes and expenditures of the population: statistical estimation, modeling and forecasting]. Finansy, oblik, banky - Finance, accounting, banks, 1. 154-162 [in Ukrainian].

13. Derzhavna sluzhba statystyky Ukrainy [State Statistics Service of Ukraine]. URL: http://www.ukrstat.gov.ua [in Ukrainian].

14. Tinova ekonomika v Ukraini. Rezultaty doslidzhennia 2019 roku [Shadow economy in Ukraine. Results of the 2019 study] Zvit Kyivskoho mizhnarodnoho instytutu sotsiolohii - report of the Kyiv International Institute Sociology. URL : http://kiis.com.ua/?lang=ukr\&cat=reports\&id=897\&page $=1 \&$ fbclid=IwAR1GSrnl614vk1GZE4QR 9yekDt_C_NMIXJ-eA0mWArZpSC3DsCgwPsZ7unw [in Ukrainian].

15. Corruption Perceptions Index 2019 : Transparency International. URL : https://www.transparency.org/cpi2019 [in English].

16. Derzhavna podatkova sluzhba Ukrainy [State Tax Service of Ukraine]. URL : www.tax.gov.ua [in Ukrainian].

17. Zakon Ukrainy Pro derzhavno-pryvatne partnerstvo: pryiniatyi 01 lyp. 2010 r. № 2404-VI [Law of Ukraine on public-private partnership from July 1 2010, № 2404-VI]. URL : https://zakon.rada.gov.ua/laws/show/2404-17 [in Ukrainian].

18. Rozporiadzhennia Kabinetu Ministriv Ukrainy Pro skhvalennia Kontseptsii derzhavnoi polityky u sferi zakhystu prav spozhyvachiv na period do 2020 roku : pryiniatyi 29 ber. 2017 r. № 217-r [Order of the Cabinet of Ministers of Ukraine on approval of the Concept of state policy in the field of consumer protection for the period up to 2020 from March 29 2017, № 217-r]. URL : https://zakon.rada.gov.ua/laws/show/217-2017-\%D1\%80 [in Ukrainian].

19. Latynin, M., Pastukh, K, Tarasenko, D., Shevchenko, S., Munko, A. (2021) Public administration in the economic sphere of Ukraine: strategic approach. Studies of applayed economics, 5. URL : http://ojs.ual.es/ojs/index.php/eea/article/view/4967 [in English]. 
Науковий вісник : Державне управління № 4(10) 2021

\title{
INSTITUTIONAL FEATURES OF STATE REGULATION OF THE CONSUMER MARKET OF UKRAINE
}

Munko Anna

\begin{abstract}
The parties to the interaction are in the institutional environment as a set of "rules of the game" (rules, guidelines, norms, sanctions, etc.), which form the economic, political, socio-legal framework of interaction between the subjects of the consumer market. The subjective structure of regulatory influence in the consumer market is represented by state, regional institutions and organizations. At the same time, these institutions are not only an institution of political power, but also a public institution that forms the socio-legal field of functioning of economic agents. These entities provide a functional basis for the implementation of organizational and institutional management of the consumer market in Ukraine. The purpose of the article is to study the institutional aspects of relations arising in the process of state influence and self-regulation of consumer markets, regulation of their development as a system of measures for state programming of the economy of Ukraine and regions. That is, the continuous process of market influence on the supply and demand, as well as the fight against the "shadow" economy, aimed at solving the challenges facing businesses and the state in conditions of economic and legal uncertainty. The article identifies the parties to the interaction of the national consumer market, scenarios of their interaction, features of formalization of such interaction, taking into account the peculiarities of the national character, as well as factors of limited rationality of the parties to the interaction. The most significant institutional problems of the market in Ukraine are substantiated. The process of organization of the consumer market of Ukraine is analyzed and the dominance of informal institutions that determine business activity and redistribution of transaction costs through informal payments are revealed. Quantitative assessment of transaction costs of business entities based on data. The ways of development of the institutional environment of state regulation of the consumer market in Ukraine are offered.
\end{abstract}

Key words: state regulation, consumer market, self-regulation of consumer markets, institutional environment, transaction costs, limited rationality of interaction between the parties 